\title{
Neuropathic pain and prognosis of a dog submitted to limb amputation after diagnosis of soft tissue sarcoma - case report
}

\author{
[Dor neuropática e prognóstico de um cão submetido à amputação de membro após diagnóstico
} de sarcoma de tecidos moles - relato de caso]

M.G.P.A. Ferreira

https://orcid.org/0000-0001-5329-3466

M.G.P.A. Ferreira ${ }^{1}$, A.V. Antunes ${ }^{2}$, A.L. Pascoli ${ }^{3}$, T.L. Nazaret ${ }^{4}$, A.P. Gering ${ }^{5}$, h.ttps://orcid.org Antunes N.P. Reis Filho ${ }^{6}$, M.T. Costa ${ }^{7}$, A.B. Nardi ${ }^{7} \quad$ h.tps://orcid.o

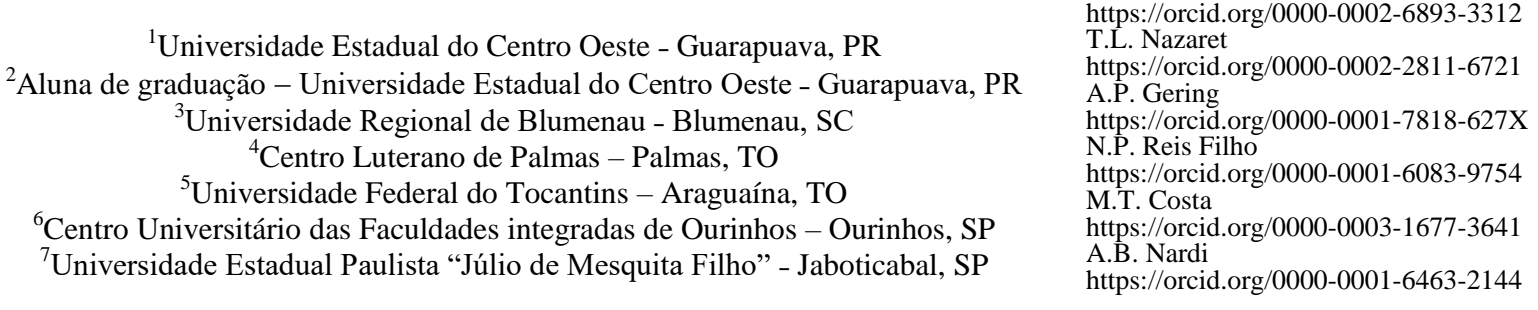

ABSTRACT

Neuropathic pain occurs when there is a lesion or a dysfunction of the nervous system. Humans and veterinary patients may develop neuropathic pain, but in veterinary it is not often reported probably because of its mistaken diagnosis. A canine patient was admitted to the Veterinary Hospital of UNESPJaboticabal-SP, Brazil with a nodule on the left thoracic limb. The nodule was surgically removed, and histopathological analysis demonstrated the tumor was a soft tissue sarcoma (STS) and the margins were not clean. Based on the patient's health condition and the lack of suitable equipment, the next procedure was limb amputation. The patient received analgesic medication in the post-surgery period; nevertheless, clinical signs of neuropathic pain were present, such as compulsive licking and other behavioral disorders. Medications were administered for forty days, but clinical signs ceased only when replaced with a tryciclic antidepressant drug, Amitriptyline. Therapeutic management of the patient in this report can be considered effective, since five years after the end of the treatment there was no recurrence or presence of metastasis.

Keywords: analgesia, oncology, phantom limb, radiotherapy, tumor

\section{RESUMO}

A dor neuropática ocorre quando há uma lesão ou disfunção do sistema nervoso. Tanto pacientes humanos quanto veterinários podem desenvolver a dor neuropática, mas na medicina veterinária ela é pouco relatada provavelmente por não ser corretamente diagnosticada. Um paciente canino foi atendido no Hospital Veterinário da Unesp-Jaboticabal, SP, Brasil, com um nódulo em membro torácico esquerdo. O nódulo foi removido cirurgicamente, e o exame histopatológico evidenciou a presença de sarcoma de tecidos moles (STM) e de margens comprometidas. Baseando-se nas condições de saúde do paciente e na ausência de equipamentos adequados, o próximo procedimento foi a amputação do membro. No pós-cirúrgico, o animal recebeu medicações analgésicas, todavia, mesmo assim, apresentava sinais de dor neuropática, como lambedura compulsiva e outros distúrbios comportamentais. $O$ tratamento para dor aguda se estendeu por 40 dias; no entanto, os sinais clínicos cessaram apenas quando os analgésicos comuns foram substituídos por um medicamento antidepressivo tricíclico, a amitriptilina. O manejo terapêutico do paciente do presente relato pode ser considerado satisfatório, uma vez que, após cinco anos do término do tratamento, não houve recidiva nem presença de metástase.

Palavras-chave: analgesia, oncologia, membro fantasma, radioterapia, tumor

Recebido em 27 de maio de 2018

Aceito em 28 de dezembro de 2018

E-mail: mary_pops1@hotmail.com 


\section{INTRODUCTION}

According to the International Association for the Study of pain (IASP), pain is defined as a distressing experience associated with actual or potential tissue damage with sensory, emotional, cognitive and social components (Williams and Craig, 2016). Neuropathic pain (NP) occurs when many different mechanisms, from the periphery to the central nervous system, involve the spinal cord, brain and descending modulation systems (Cohen and Mao, 2014).

NP is well-recognized in human medicine but is difficult to diagnose and characterize in small animals (Cashmore et al., 2009). It is known to be one of the most difficult pain syndromes to handle (Williams and Craig, 2016). As Madden et al. (2014) indicated, NP should be considered in patients with chronic and misleading symptoms of pain. Some clinical signs that may suggest neuropathic pain in dogs are allodynia, hyperalgesia, dysesthesia (spontaneous pain) and paroxysmal pain episodes (Cashmore et al., 2009). The understanding of the neurobiology of pain is in constant advance, however, the pharmacological management of pain syndromes remain insufficient and several drugs have failed in the late-stage (Finnerup et al., 2015).

Cancer pain may induce NP because of tumor growth and compression of nervous structures causing tissue injury (Smith and Saiki, 2015). Neuropathic pain is a common complication after amputation. About $80 \%$ of human patients report clinical signs related to NP after this procedure (Silva et al., 2008).

Soft tissue sarcomas are mesenchymal cancer, which can affect many tissues in the body, but the skin and subcutaneous tissues are the most commonly affected areas. The main treatment for this kind of cancer is wide surgical resection. Prognosis is often good, and the rate of metastasis in dogs ranges from 8 to $17 \%$ in sarcomas grade I and II. Sarcomas grade III are known to methastize in $40 \%$ of the cases (Jark et al., 2016).

Since there is lack of reports on neuropathic pain in domestic animals having undergone amputation, the aim of this case report is to describe the clinical findings and therapeutic management for what appeared to be neuropathic pain in a middle-aged dog, caused after an amputation of the left thoracic limb, due to a soft tissue sarcoma and to report the clinical outcome of this patient.

\section{CASE REPORT}

A 7-year-old female spayed dog was admitted to the oncology service at the Veterinary Hospital of UNESP - Univ Estadual Paulista, JaboticabalSP, Brazil. The dog weighted $6.8 \mathrm{~kg}$ and had a history of a nodule on the left thoracic limb for about 7 to 10 days. It also had a history of previous renal disease but had received no therapy. Clinical evaluation revealed no significant systemic alterations. The nodule was then specifically examined. It was a soft, nonulcerated, non-alopecic, with a loose $2.0 \times 2.5 \times$ $1.0 \mathrm{~cm}$ mass in the middle third of the left radioulna (Figure 1).

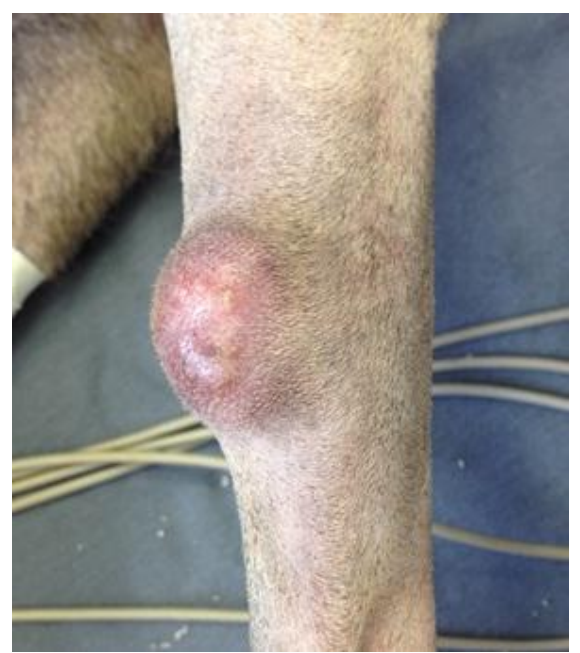

Figure 1. Nodule on the left radio-ulna bones in a 7 -year-old dog with $2.0 \times 2.5 \times 1.0 \mathrm{~cm}$.

The patient showed no painful sensitivity to manipulation of the nodule. Palpation of lymph nodes showed no painful sensitivity, no significant changes in size, consistency or temperature. X-ray images of the chest were taken and analyzed for pulmonary metastasis, which result was negative. It was also possible to see that the mass was not invading bone tissue. Abdominal ultrasound showed a slight bilateral decrease of the patient's kidneys size.

Laboratory evaluation (complete blood count and biochemical) showed only a slight increase in serum creatinine value $(1.9 \mathrm{mg} / \mathrm{dL})$. Urine 
examination, blood pressure measurement and urinary protein-to-creatinine ratio were also evaluated. No alteration was seen. As part of the complementary exams, the fine needle aspiration (FNA) of the nodule was performed, in which the presence of red blood cells, few inflammatory cells and reactive fibroblasts were observed on the microscope. Given the results, an excisional biopsy of the nodule was the first treatment option. The patient received preanesthetic medication with $0.3 \mathrm{mg} / \mathrm{kg}$ Morphine (Dimorf®, Morfina 10mg, Cristália Prod. Quím. Farm. Ltda, Brazil) and $0.3 \mathrm{mg} / \mathrm{Kg}$ Midazolam (Dormonid®, Midazolam 5mg, Cristália Prod. Quím. Farm. Ltda, Brazil) intra muscular (IM) and underwent general anesthesia with $5.0 \mathrm{mg} / \mathrm{kg}$ Propofol (Propovan®, Cristália Prod. Quím. Farm. Ltda, Brazil) intravenous (IV) for induction, then Isoflurane (Isoforine ${ }^{\circledR}$, Cristália Prod. Quím. Farm. Ltda, Brazil) to maintain. Because of the large surgical margin attempt, an axial pattern flap was made to close the surgical wound.

The material was sent for histopathological analysis, and the result was compatible with intermediate grade sarcoma with compromised margins microscopically identified. Since the surgery did not have the expected outcome, it was decided to perform the amputation of the limb (Figure 2). Five days before the second intervention, $10 \mathrm{mg} / \mathrm{Kg}$ Gabapentin (every 12 hours) administration was initiated. To amputate the limb, the patient was submitted to the same anesthetic protocol as the first intervention, but local anesthesia with Lidocaine $2 \%$ (Xylocaína® solução injetável 2\%, Astra Química $e$ Farmacêutica Ltda, Brazil) was also performed.

The scapula was removed according to Schulz's (2013) technique: a skin incision to the dorsal border of the scapula, over the scapular spine was made, then omotransversarius, trapezius and rhomboideus muscles were transected. After that, serratus was transected, along with suprascapular and subscapular nerves, teres major and the long head of the triceps muscles, coracobrachialis tendon, teres minor, infraspinatus, supraspinatus, and subscapularis muscles. The joint capsule was incised, and the scapula was removed. Axillary and pre-scapular lymph nodes were also removed, and histopathological analysis showed that it was not involved by neoplastic cells.

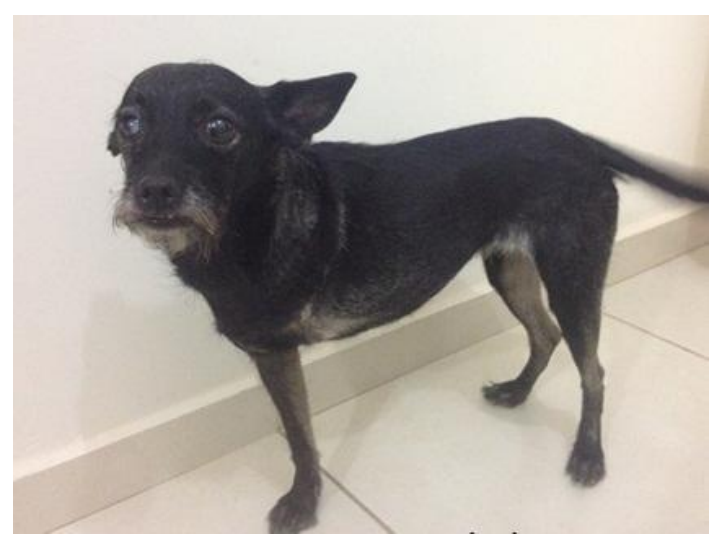

Figure 2. Limb amputation in a 7-year-old dog, after histopathological analysis with the result compatible with intermediate grade sarcoma with compromised margins microscopically identified.

To prevent self-injury after surgery, the animal had to be kept with a pet cone. $30 \mathrm{mg} / \mathrm{kg}$ Cephalexin (twice a day) was prescribed for 7 days, $3.5 \mathrm{mg} / \mathrm{kg}$ Tramadol (every 8 hours) for 14 days, $25 \mathrm{mg} / \mathrm{kg}$ Dipyrone (every 8 hours) for 10 days, $2 \mathrm{mg} / \mathrm{kg}$ Ranitidine (every 8 hours) for 10 days and $10 \mathrm{mg} / \mathrm{kg}$ Gabapentin (twice a day) until further recommendations. Local cleaning with $0.9 \%$ saline for 14 days was also prescribed.

After 14 days, the patient returned hyporetic, lethargic, with too much sensitivity at the surgery site and avoided lying down on the intervention site. Without the pet cone, it would compulsively lick the surgical wound. No alterations were observed at clinical evaluation. The wound was well healed, with no signs of infection or edema. While the palpation of the amputated site was being done, the patient showed high sensitivity, seen by vocalization and in some moments, aggressiveness.

CBC (Complete Blood Count) and biochemical exams were repeated, which showed only a slight increase in creatinine $(1.78 \mathrm{mg} / \mathrm{dL})$. Tramadol and Dipyrone were maintained for seven more days, together with Gabapentin until further recommendations. Due to the renal illness and low response of STS to antineoplastic therapy, it was decided against chemotherapy. After 25 days of the second surgical intervention, the patient returned with the same clinical signs: hyporexia, lethargy, high sensitivity at the surgery site. At this moment the patient was only on Gabapentin P.O. Gabapentin was maintained 
and the patient was being periodically reassessed. After 60 days, clinical signs, physical evaluation, $\mathrm{CBC}$ and biochemical exams were the same as previously, except for creatinine $(1.84 \mathrm{mg} / \mathrm{dL})$. A presumptive diagnosis of NP (neuropathic pain) or phantom limb sensation was made, and Gabapentin was then replaced by $8 \mathrm{mg} / \mathrm{kg}$ Amitriptyline (twice a day).

After 15 days on Amitriptyline, the patient returned for reassessment. The owner reported a marked improvement in the clinical picture. The animal went back to normal feeding, was more active, and began to lie on the side of amputation, although it sometimes still avoided that. The owner was trying to keep it without the pet cone, but the dog licked the site of surgery, although the frequency and intensity had declined considerably.

After 60 days of Amitriptyline administration, the patient was evaluated again. The owner did not notice any changes on the pet's overall condition, except that it rarely tried to lick the area. No clinical abnormalities were noticed, and the medication was maintained until further recommendations. Amitriptyline was the only medication able to bring full resolution of clinical signs in this patient. Examinations were done every four months, and they showed the patient had had no recurrence or metastasis.

\section{DISCUSSION}

Soft tissue sarcomas are invasive neoplasms with low metastatic potential. Surgery, radiation therapy, and chemotherapy are the main treatment options for STS in dogs. According to Jark et al. (2016), the cornerstone of treatment for low-to-intermediate-grade soft-tissue sarcomas is wide and aggressive excision. The margins must be over 2 to $3 \mathrm{~cm}$ in all planes and/or fascial plane in depth. In the present report, the patient was initially submitted to a wide but conservative surgical procedure. However, due to the results of histopathological analysis, in which the presence of compromised margin was found, amputation of the limb was the chose course.

In cases in which clean surgical margins are not achieved, it is suggested that the treatment be followed by radiotherapy or radiotherapy plus chemotherapy (LaRue and Cutis, 2014). As
LaRue and Custis (2014) described, options of radiotherapy are megavoltage, orthovoltage or megavoltage $\mathrm{x}$ ray. Linear accelerators produce high energy $x$-rays and unlike orthovoltage radiation, it spares skin and has a greater depth of penetration. Since STS is a very invasive tumor, it is indicated for its treatment. Metronomic chemotherapy, known as an uninterrupted administration of chemotherapy drugs at lower doses than maximum tolerated dose therapy, with cyclophosphamide and piroxicam, could also be used postoperative. The patient had a history of chronic kidney disease, so chemotherapy was not very interesting because it could cause more renal damage, and due to the unavailability of linear accelerator machines in Brazil at that time, the treatment of choice had to be limb amputation.

Metastasis is uncommon for grade I and II tumors (as seen in this report) and most likely appear when there is a grade III tumor (Dennis et al., 2011). To prevent or delay recurrence after surgery, a combination of marginal resection and radiation treatment is believed to have the same results as radical resection alone (McKnight et al., 2000). The survival rate of five years reported in a study by McKnight et al. in 2000 was $76 \%$ with radical resection. The present report shows that amputation was very effective for this patient, since five years later the dog is alive and without signs of metastasis or recurrence. It could be considered free from STS.

Limb amputation is often linked to phantom limb pain in humans. To decrease its occurrence, preemptive analgesic such as local anesthesia (epidural, perineural analgesia), preoperative opiates and NMDA receptor antagonists are administered (O’Hagan, 2006). In this dog, presurgical analgesia was administered using opiate and myorelaxant drugs. Intraoperative use of local anesthetics was applied on the brachial plexus. Despite following a recommended anesthetic/analgesic protocol, the dog still appeared to develop post-surgical neuropathic pain. It is challenging to identify neuropathic pain in animals because there haven't been enough studies or reports on this.

O'Hagan (2006) reported a case of a cat that underwent a leg amputation, and after 38 days of the procedure, it was displaying unusual behavior such as hiding, urinating 
inappropriately, trying to shake the amputated limb. After 60 days the cat was very lethargic. In the present report, the patient presented hyporexia, lethargy, too much sensitivity at the surgery site, avoided laying down on the intervention site and compulsively licked the surgical wound. Amitriptyline is a tryciclic antidepressant drug used in the management of behavioral disorders in small animals and was administered in both cases, bringing full resolution of clinical signs. Another study showed that Amitriptyline or Gabapentin administration resulted in either an improvement or complete resolution of NP (Cashmore et al., 2009).

\section{CONCLUSION}

There is a lack of reports on neuropathic pain or phantom limb pain in small animals, which is concerning because limb amputation is a very common procedure and neuropathic pain may be neglected or incorrectly diagnosed. Soft tissue sarcoma is an aggressive and highly invasive kind of tumor. Sarcoma tumors can be managed either with excision (being radical or not), associated with chemotherapy and/or radiotherapy, radiotherapy alone or chemotherapy alone. In certain cases, it is not possible to perform radiotherapy or chemotherapy due to the patient's health condition or availability of suitable equipment. This report showed that in those cases radical excision is a plausible option. Surgery and anesthetic protocol must be well planned to decrease the chances of postoperative neuropathic pain syndrome. Clinical examination must be constant to evaluate behavioral disorders and clinical signs. If neuropathic pain occurs, there are drugs such as Gabapentin or Amitriptyline, which bring great clinical outcome.

\section{REFERENCES}

CASHMORE, R.G.; HARCOURT-BROWN, T.R.; FREEMAN, P.M. Clinical diagnosis and treatment of suspected neuropathic pain in three dogs. Aust. Vet. J., v.87, p.45-50, 2009.
COHEN, S.P.; MAO, J. Neuropathic pain: mechanisms and their clinical implications. $\mathrm{Br}$. Med. J., v.348, p.7656, 2014.

DENNIS, M.; MCSPORRAN, D.; BACON, N. et al. Prognostic factors for cutaneous and subcutaneous soft tissue sarcomas in dogs. Vet. Pathol., v.48, p.73-84, 2011.

FINNERUP, N.B.; ATTAL, N.; HAROUTOUNIAN, S. et al. Pharmacotherapy for neuropathic pain in adults: a systematic review and meta-analysis. Lancet Neurol., v.14, p.162-173, 2015.

JARK, P.C.; FILHO, N.P.R.; FERREIRA, M.G.P.A. et al. Sarcomas de tecidos moles cutâneos e subcutâneos em cães. In: DALECK, C.R.; NARDI, A.B. Oncologia em cães e gatos. Rio de Janeiro: Roca, 2016. p.517-529.

LARUE, S.M.; CUSTIS, J.T. Advances in veterinary radiation therapy: targeting tumors and improving patient comfort. Vet. Clin. N. Am. Small Anim. Pract., v.44, p.909-23, 2014.

MADDEN, M.; GURNEY, M.; BRIGHT, S. Amantadine, an N-Methyl-D-Aspartate antagonist, for treatment of chronic neuropathic pain in a dog. Vet. Anaesth. Analg., v.41, p.440441, 2014.

MCKNIGHT, J.A.; MAULDIN, G.N.; MCENTEE, M.C. et al. Radiation treatment for incompletely resected soft-tissue sarcomas in dogs. J. Am. Vet. Med. Assoc., v.217, p.205-210, 2000.

O'HAGAN, B.J. Neuropathic pain in a cat postamputation. Aust. Vet. J., v.84, p.83-86, 2006.

SCHULZ, K.S. Other Diseases of Bones and Joints In: FOSSUM, T.W. Small animal surgery. St. Louis, Missouri: Elsevier, 2013. p.1400-1402.

SILVA, F.C.; MORENO, F.C.B.; BENDER, P.F.M. et al. Prevenção da dor fantasma com uso de cloridrato de amitriptilina. Rev. Bras. Cancerol., v.54, p.345-349, 2008.

SMITH, T.J.; SAIKI, C.B. Cancer pain management. Mayo Clin. Proc., v.90, p.14281439, 2015.

WILLIAMS, A.C.C.; CRAIG, K.D. Updating the definition of pain. Pain, v.157, p.2420-2423, 2016. 